\title{
Body-Image and Obesity in Adolescence: A Comparative Study of Social-Demographic, Psychological, and Behavioral Aspects
}

\author{
Pedro Miguel Lopes de Sousa \\ Universidade de Coimbra (Portugal)
}

\begin{abstract}
In current society, body and beauty's cult emerge as one of the main factors of adolescence. That leads adolescents to be dissatisfied with their own appearance, to psychological maladjustment, and nutritional disorders. This quantitative, exploratory, and cross-sectional research evaluates how adolescents perceive their weight and the prevalence of obesity in a sample of adolescents from the district of Viseu (Portugal). It also attempted to compare the relation of body-image and obesity with sociodemographic (school, sex, age, socioeconomic status, family functioning), psychological (self-concept, depression, school success) and behavioral aspects (physical inactivity). After data analyses, it was verified that the prevalence of obesity was $8.8 \%$ but $12.7 \%$ considered themselves obese. These adolescents had higher physical inactivity, poorer family functioning, a lower self-concept, and a higher depression index. The really obese adolescents were older and had poorer academic results. Obesity was higher in boys, but girls perceived themselves more as being obese. In conclusion, it is essential to evaluate weight perception in addition to body mass index (BMI), because the main problem could be related not only to being obese, but also to the perception of having a higher than ideal weight.
\end{abstract}

Keywords: body-image, obesity, social-demography, psychology, behavior

\begin{abstract}
En la sociedad actual, el culto al cuerpo y la belleza emergen como uno de los principales factores en la adolescencia. Esto lleva a los adolescentes a sentirse insatisfechos con su propio aspecto, al desajuste psicológico y a los trastornos de alimentación. Esta investigación cuantitativa, exploratoria y transversal evalúa cómo los adolescentes perciben su peso y la prevalencia de la obesidad en una muestra de adolescentes del distrito de Viseu (Portugal). También intenta comparar la relación entre imagen corporal y obesidad con aspectos sociodemográficos (escuela, sexo, edad, nivel socioeconómico, funcionamiento familiar), psicológicos (autoconcepto, depresión, eventos escolares) y comportamentales (inactividad física). Después de analizar los datos, se verificó que la prevalencia de la obesidad era de $8,8 \%$ pero que un $12,7 \%$ se consideraban obesos. Estos adolescentes tenían un mayor nivel de sedentarismo, un funcionamiento familiar peor, autoconcepto más bajo y un alto índice de depresión. Los adolescentes realmente obesos eran mayores y tenían peores resultados académicos. La obesidad era más alta entre los chicos pero las chicas se percibían como obesas. En conclusión, es fundamental evaluar la percepción del peso además del índice de masa corporal porque el problema principal podría estar relacionado no sólo con ser obeso, sino también con la percepción de tener un peso mayor que el peso ideal.

Palabras clave: trauma, atentados terroristas, estrés, depresión, resiliencia, epidemiología
\end{abstract}

Correspondence concerning this article should be addressed to Pedro Miguel Lopes de Sousa, Urbanizaçao de S. Jorge, Fracção G, 3140-446 Seixo de Gatões (Portugal). E-mail: pmlsousa@gmail.com

How to cite the author of this article: Sousa, P.M.L. 
The current life style, based on advanced technologies, contributes to the decrease in levels of physical activity and leisure, a phenomenon associated with the increase in consumption of hypercaloric foods and obesity. Simultaneously, social pressures push for thinness, according to rigid standards for beauty that demand ever thinner anthropometric profiles (Bosi, Luiz, Morgado, Costa, \& Caravalho, 2006). In fact, social representations of the ideal body are anchored in images of youth, beauty, vigor, and health. Social communications media perpetuate this "obsession with appearance" that society itself constructs. Seeking to identify with a social group has brought Man to conformity and approximation to these standards, causing the emergence of the concept of the "deviant individual" indicating anyone who fails to meet these standards. These individuals are considered to have an imperfect body, causing feelings of inadequacy and discriminatory feelings on the part of others (Santos \& Sawaia, 2000).

That is, body image seems to be a concept of growing importance in our daily lives, defined as the mental image of our own body, which is, the method by which we present or experience our own bodies (Bosi et al., 2006). For Slade (1988, in Bosi et al., 2006), the term bodily image refers to a mental illustration of the size, image, and shape of the body, with an associated emotional dimension. Body image is defined as the interaction between the perceptive component, or cognitive evaluation of body size, and the postural component, as complex affective-cognitivebehavioral response to this evaluation (Segal, Cardeal, \& Cordás, 2002).

According to Thompson (1996, in Saikali, Soubhia, Scalfaro, \& Cordás, 2004), the concept of body image involved three components: perceptive, which related to the precision of the perception of one's own physical appearance, involving a estimation of the body size and weight; subjective, which involved aspects such as satisfaction with the appearance, the level of associated preoccupation and anxiety; behavioral, which focuses on the situations the individual avoids in order to avoid discomfort associated with the bodily appearance.

To sense one's own body, to see or perceive one's own body are central aspects present in the majority of the conceptualizations about bodily image, nearly always rooted in the Schilder's (1923, in Santos \& Sawaia, 2000) class definition, for which the bodily image is a mental picture or perception that someone holds regarding their own body. It is a multidimensional, dynamic, mutable, and fundamentally social construct, formed from a complex combination of attitudes, feelings, and values, anchored in the representations and stereotypes that social groups value and convey throughout time.

It is through the bodily image that the individual maintains an internal equilibrium while interacting with the world, since this provides them the sense of identity and influences their behavior (Santos \& Sawaia, 2000). This dynamic interaction between the subjective and the social causes us to perceive our body in a manner similar to that in which everyone does, but, simultaneously, in a completely individualized way. Thus, the significance of the body image becomes intimately related with others, such as self-concept, self-esteem, self image, bodily concept and bodily scheme (Cohen, 1991, in Santos \& Sawaia, 2000).

These concepts about valued bodily images impose the necessity for reflection on health and illness, representation that emanate from the social, and, this, are influenced by beliefs, expectations, and our very culture. Being thus, since obesity is an epidemic in the 20th century, and has become immersed in a markedly stigmatized context, it seems relevant to analyze the manner in which body image or representation of weight influences the socio-demographic, psychological, and behavioral aspects of the obese and nonobese individual.

In fact, obese persons are a target of preconception and discrimination, attend school for fewer years, have a lower probability of being accepted into more competitive schools or jobs, have lower salaries, and less stable romantic relationships (Segal et al., 2002). On the other hand, dissatisfaction with the body has frequently been related to a discrepancy between the perception and the desired body size and shape (Bosi et al., 2006).

However, this stigma of obesity arises largely in adolescence, a period of elevated risk for development of an imbalances bodily image. This is because adolescents with excessive weight or obesity perceive their difference, and hear rude, even offensive comments from classmates, causing them to limit their athletic activities and social life. Also, the Universidade Estatal de Campinas (State University of Campinas, 1997) adds that persistent obesity during school age brings the child to develop psychological problems related to the comments and jokes to which they become subject on the part of their colleagues. Cruz (1983) confirms that some of the social consequences are discrimination, difficulty with cultural integration, and deterioration of the self-image. Thus, it is clear that further research is needed in this area, since only an increase in knowledge enables effective intervention.

Despite body image not being frequently investigated in treatment of obesity, there is a growing awareness of its importance due to the inherent advantages in obtaining a better body image and improvement in overall levels of maintenance of the therapeutic regimen (Segal et al., 2002). In fact, body image appears to have an unequivocal importance in all aspects of the individual, especially in reference to obesity. Still, there are some studies that emphasize the fact that body image plays a more important role than the body mass index (BMI) in the development of complications associated with obesity. An example of this is the study of Faith and Allison (1996, in Segal et al., 2002) which concluded that there is no direct relation between the BMI and dissatisfaction or distortion of the 
body image (not even with real excess weight), but that there was with perceived excess weight. Nunes, Olinto, Barros and Camey (2001) verified that perception of body weight (to feel fat) played a more important role in the determination of abnormal eating habits than the BMI.

It is in this context that the present study arises, with the intent to evaluate how adolescents perceive their weight, as well as the prevalence of obesity in the study sample. This study aims, as well, to determine the relationship between body image and obesity with socio-demographic, psychological, and behavioral aspects in adolescents.

\section{Method}

\section{Participants}

In the pursuit of the chosen objectives, a quantitative, exploratory, cross-sectional study was chosen, defining the study population as adolescents attending secondary school in the Viseu district (region in the northern interior of Portugal), with eleven secondary schools selected for study (see Table 1). Considering the impracticality of analyzing all of the individuals in the population with the available time and resources, a sample of 1198 individual was selected, as this sample was not problematic.

Regarding academic levels, it was verified that $40.7 \%$ had completed their $10^{\text {th }}$ year school, $28 \%$ had completed the $11^{\text {th }}$, and $31.3 \%$ had completed the $12^{\text {th }}$ year. Of the 1198 participants in the study, 701 were female $(58.5 \%)$ and 497 were male $(41.5 \%)$. As far as age, the minimum age of the sample was 15 years, and the maximum was 22 years, corresponding to an average age of 16.79 years and a standard deviation of 1.24. The age limits for adolescence are very controversial, and there are different opinions on the matter, despite the usual consideration being that the upper limit is 18 years. However, in this study, we follow the guidelines from Medeiros (2000), Muuss (1976, in Martins, Trindade, \& Almeida, 2003) and of the World Health Organization itself, which has considered youths to be in the age range between 15 and 24 years (TraversoYepez \& Pine, 2002). In any case, according to Developmental Psychology, adolescence is characterized by an array of physical, psychological, social, and moral transformations, and not by a specific age range that may be too restrictive.

\section{Instruments and Procedure}

This, in this study, the instrument for data collection used was a questionnaire composed of closed, open and mixed questions intended for the characterization of the sample and evaluation of the selected variables. Data collection occurred during the years 2002 and 2003, in the selected school, confidentiality and anonymity being guaranteed, and informed consent from the school administrations, parents and student who voluntarily responded to the questionnaire.

For this study, two dependent variables were defined (body image and obesity) due to the nature of research, and as independent variables, the following were chosen: school, gender, age, physical inactivity, socioeconomic level, family functionality, self-concept, depression, and academic success.

Body image was evaluated using a closed question with one answer in which the adolescents described themselves as "thin", "normal" or "fat". Obesity was evaluated using a BMI greater than $25 \mathrm{~kg} / \mathrm{m}_{\text {_ }}$ as the cut-off point for adolescents of both genders. We chose not to consider a BMI greater than $30 \mathrm{Kg} / \mathrm{m}_{-}$as various authors defend, since this criterion can only be used when the physical structure/composition of the adolescents approximates that of adults. To avoid erroneous results, some authors have chosen to consider excess weight and obesity as a single concept, and to use the BMI greater than 25 as the criterion,

Table 1

Distribution of Samples in the Schools

\begin{tabular}{lrr}
\hline Secondary schools & $N$ & $\%$ \\
\hline Resende & 41 & 3.4 \\
Mangualde & 6 & 0.5 \\
Carregal do Sal & 58 & 4.8 \\
S.J. Pesqueira & 69 & 5.8 \\
S. Pedro do Sul & 224 & 18.7 \\
Mortágua & 160 & 13.4 \\
Castro Daire & 266 & 22.2 \\
Lamego (Latino Coelho) & 50 & 4.2 \\
Moimenta & 38 & 3.2 \\
Cinfães & 222 & 18.5 \\
Viseu (Viriato) & 64 & 5.3 \\
& 1198 & 100.0 \\
\hline
\end{tabular}


as in the case of the study of Monteiro, Victora, Barros and Tomasi (2000), with which we agree. In this study, a selfdeclared BMI was used (calculated from the formula: weight/height ${ }^{2}$ ) due to logistical and methodological imperatives, its validity being duly saved (Fonseca, Faerstein, Chor, \& Lopes, 2004).

The independent variables of school, age, and gender, were evaluated through open questions. To estimate the level of physical inactivity, a measurement scale composed of participation in sports, frequency, number of hours watching television or on the computer, was used (Gomes, Ferreira, Rocha, Almeida, \& Sousa, 2004). The scale provides a total index that may be grouped into three classes according to the psychometric data provided by the authors: group 1 individuals with high levels of physical inactivity, group 2 - individuals with regular levels of physical inactivity, and group 3 - individuals with low levels of physical inactivity. The socioeconomic level was inferred through the Grafar index (Sousa, 1999), the total index of the grouped scale being divided into five classes: 5 to 9 - upper class; 10 to 13 - upper middle class; 14 to 17 - middle class; 18 to 20 - low middle class; 22 to 25 - low class. Family functionality (the perception that the individual has of the fundamental components of family function: intra-familiar adaptation, participation/communication, growth/development, affection and resolution/dedication) was approached using the APGAR family scale created by Smilkstein (Smilkstein, Ashworth, $\&$ Montano, 1982). The final result was obtained using the sum of scores attributed to each of the questions. An overall score of 7 to 10 suggests a highly functional family; 4 to six, a family with moderate dysfunction, and 0 to 3 being a highly dysfunctional family (Sousa, 1999).

Self-concept was evaluated using the Clinical SelfConcept Inventory of Vas Serra (1986), while depression was evaluated using the Beck Depression Inventory (BDI; Beck, Rush, Shaw, \& Emery, 1979; translated by Gorestein \& Andrade, 1998). The BDI scale provides a total index that can be interpreted as follows: less than 10 represents the absence of depression; from 10 to 18 indicates light depression; 10 to 29 indicates moderate depression; 30 to 63 indicates severe depression. Finally, academic success was measured by the number of failures (throughout the academic career).

\section{Statistical Analyses}

Statistical treatment of the data was conducted with non parametric tests, since the normality of the data distributions was not verified, tested using the Kolmogorov-Smirnov test, with Lilliefors correction, and with the Shapiro-Wilk test (Pestana \& Gageiro, 1998). To test for the existence of statistically significant differences between the three classes of body image in the adolescents, the Kruskal-Wallis test was used, while the Mann-Whitney test was used to evaluate differences between the two BMI types. When it was intended to relate two variables, such as: classes of body image, obesity, school, gender, classes of physical inactivity, socioeconomic classes, classes of family functionality, and classes of depression, the choice fell to chi-square test (Pestana \& Gageiro, 1998). The software SPSS version 14.0 was used for data analysis. We should emphasize, again, that the level of significance of .05 was used in this study.

\section{Results}

After analysis of the obtained results, regarding body image, it was noted that the majority of adolescents questioned consider themselves to be "normal" (71.5\%), while $15.8 \%$ considered themselves to be "thin", and $12.7 \%$ considered themselves to be "fat" (Table 2).

The statistics relative to the BMI showed that the minimum value found was $14.2 \mathrm{~kg} / \mathrm{m}^{2}$ and the maximum value was $54.6 \mathrm{~kg} / \mathrm{m}^{2}$, corresponding to an average of 21.7 $\mathrm{kg} / \mathrm{m}^{2}$ and a standard deviation of 2.8. Grouping the BMI data into classes, it was verified that the non-obese adolescents $\left(<25 \mathrm{Kg} / \mathrm{m}^{2}\right)$ comprised $91.2 \%$ of the sample, while obese adolescents $\left(\leq 25 \mathrm{Kg} / \mathrm{m}^{2}\right)$ constituted $8.8 \%$ of the individuals (see Table 2).

Subsequently, the ways in which body image and obesity in adolescents relate with the remaining evaluated variables was analyzed.

Table 2

Sample Distribution as a Function of Body Image and Types of Obesity (BMI)

\begin{tabular}{|c|c|c|c|c|}
\hline Variable & & & $N$ & $\%$ \\
\hline \multirow{3}{*}{ Body image } & Thin & & 189 & 15.8 \\
\hline & Normal & & 857 & 71.5 \\
\hline & Fat & & 151 & 12.7 \\
\hline \multirow{4}{*}{ Obesity (BMI) } & & Total & 1197 & 100.0 \\
\hline & Not obese & & 1093 & 91.2 \\
\hline & Obese & & 105 & 8.8 \\
\hline & & Total & 1198 & 100.0 \\
\hline
\end{tabular}

Note . BMI = Body Mass Index. 


\section{School}

Considering the relationship between the school attended by the participants and their body image, the absence of statistically significant relationships was verified. $\left(\chi^{2}=\right.$ 23.709, $p=.255$ ) (see Table 3), despite the fact that the percentage of adolescents who considered themselves to be "fat" was considerably greater in schools at Moimenta da Beira (21.1\%), Mortágua (17.5\%) and Viseu (15.6\%). Through analysis of Table 3, it was observed that the Secondary School at Moimenta da Beira was that which exhibited the greatest percentage of $(21.1 \%)$ of cases of obesity, followed by the Escola Secundária Viriato (Viseu) with $12.5 \%$, while the schools at Resende and Mangualde had no cases of obesity. However, these differences are not statistically significant $\left(\chi^{2}=14.718, p=.143\right)$.

\section{Gender}

Use of chi-square test between gender and body images did show statistically relevant differences $\left(\chi^{2}=16.860, p\right.$ $=.000)$ (see Table 4$)$, since the percentage of girls that considered themselves to be "fat" $(15.9 \%)$ was greater than boys $(8.0 \%)$. Still, in Table 4 , one may verify that $5.3 \%$ of the girls really are obese, while this percentage among boys reached $13.7 \%$, these differences being statistically significant $\left(\chi^{2}=25.685, p=.000\right)$.

Age

Relating age with body image in adolescents through the Kruskal-Wallis test, it was verified that individuals who consider themselves "fat" tend to be older (16.81) than individuals who consider themselves to be "thin" (16.68), although these differences are not statistically significant $(H=1.637, p=.441)$ (see Table 5). All the same, when the BMI classes are compared with the age of the subjects, statistical differences are found $(U=43783.50, p=.000)$ (see Table 5). In fact, it was noted that obese adolescents have a greater average age (17.25) than non-obese adolescents (16.75 years).

\section{Physical Inactivity}

In the analysis of the physical inactivity index, the minimum value found in the measurement scale was 1 , and the maximum value was 36 , the average being 8.14 with a

Table 3

Chi-Square Test of Schools as a Function of Body Image and Obesity (BMI)

\begin{tabular}{|c|c|c|c|c|c|c|c|c|c|}
\hline \multirow{2}{*}{ Secondary schools } & \multicolumn{3}{|c|}{ Body image } & \multicolumn{6}{|c|}{ Obesity (BMI) } \\
\hline & Thin $(\%)$ & Normal (\%) & Fat $(\%)$ & $\chi^{2}$ & $p$ & Not Obese (\%) & Obese $(\%)$ & $\chi^{2}$ & $p$ \\
\hline Resende & 12.2 & 80.5 & 7.3 & & & 100.0 & 0.0 & & \\
\hline Mangualde & 33.3 & 66.7 & 0.0 & & & 100.0 & 0.0 & & \\
\hline Carregal do Sal & 12.1 & 75.9 & 12.1 & & & 89.7 & 10.3 & & \\
\hline S.J. Pesqueira & 17.4 & 78.3 & 4.3 & & & 91.3 & 8.7 & & \\
\hline S. Pedro do Sul & 17.4 & 68.8 & 13.8 & & & 92.9 & 7.1 & & \\
\hline Mortágua & 15.6 & 66.9 & 17.5 & 23.709 & .255 & 90.0 & 10.0 & 14.718 & .143 \\
\hline Castro Daire & 13.9 & 72.6 & 13.5 & & & 92.5 & 7.5 & & \\
\hline Lamego & 18.0 & 72.0 & 10.0 & & & 92.0 & 8.0 & & \\
\hline Moimenta da Beira & 15.8 & 63.2 & 21.1 & & & 78.9 & 21.1 & & \\
\hline Cinfães & 19.0 & 71.9 & 9.0 & & & 90.5 & 9.5 & & \\
\hline Viseu & 7.8 & 76.6 & 15.6 & & & 87.5 & 12.5 & & \\
\hline
\end{tabular}

Note. BMI $=$ Body Mass Index.

Table 4

Chi-Square Test of Sexes as a Function of Body Image and Obesity (BMI)

\begin{tabular}{|c|c|c|c|c|c|c|c|c|c|}
\hline \multirow{2}{*}{ Sex } & \multicolumn{3}{|c|}{ Body image } & \multicolumn{6}{|c|}{ Obesity (BMI) } \\
\hline & Thin $(\%)$ & Normal (\%) & Fat $(\%)$ & $\chi^{2}$ & $p$ & Not Obese $(\%)$ & Obese $(\%)$ & $\chi^{2}$ & $p$ \\
\hline Female & 14.4 & 69.7 & 15.9 & \multirow{2}{*}{16.860} & \multirow{2}{*}{$.000 * *$} & 94.7 & 5.3 & \multirow{2}{*}{25.685} & \multirow{2}{*}{$.000 * *$} \\
\hline Male & 17.7 & 74.2 & 8.0 & & & 86.3 & 13.7 & & \\
\hline
\end{tabular}

Note. $\mathrm{BMI}=$ Body Mass Index.

$* * p<.01$. 
Table 5

Comparison of the Types of Body Image (Kruskal-Wallis Test) and Types of Obesity (BMI, Mann-Whitney Test) as a Function of the Variables Studied

\begin{tabular}{|c|c|c|c|c|c|c|c|c|}
\hline Variables & Body image & $M$ & $H$ & $p$ & Obesity & $M$ & $U$ & $p$ \\
\hline & Thin & 16.68 & & & Not obese & 16.75 & & \\
\hline \multirow[t]{4}{*}{ Age } & Normal & 16.81 & 1.637 & .441 & & & 43783.50 & $.000 * *$ \\
\hline & Fat & 16.81 & & & Obese & 17.25 & & \\
\hline & Thin & & & & & & & \\
\hline & Thin & 19.83 & & & & & & \\
\hline \multirow[t]{3}{*}{ BMI } & Normal & 21.63 & 234.521 & $.000 * *$ & & & & \\
\hline & Fat & 24.24 & & & & & & \\
\hline & Thin & 8.34 & & & Not obese & 8.18 & & \\
\hline \multirow[t]{3}{*}{ Sedentariness } & Normal & 8.01 & 8.403 & $.015^{*}$ & & & 53196.00 & .214 \\
\hline & Fat & 8.65 & & & Obese & 7.75 & & \\
\hline & Thin & 15.07 & & & Not obese & 15.10 & & \\
\hline \multirow[t]{3}{*}{ Socioeconomic class } & Normal & 15.12 & 0.034 & .983 & & & 54822.50 & .446 \\
\hline & Fat & 15.19 & & & Obese & 15.36 & & \\
\hline & Thin & 6.14 & & & Not obese & 6.57 & & \\
\hline \multirow[t]{3}{*}{ Family functionality } & Normal & 6.82 & 21.097 & $.000 * *$ & & & 53068.50 & .199 \\
\hline & Fat & 5.89 & & & Obese & 6.87 & & \\
\hline & Thin & 63.50 & & & Not obese & 63.83 & & \\
\hline \multirow[t]{3}{*}{ Self-concept } & Normal & 64.19 & 7.237 & $.027 *$ & & & 55834.00 & .647 \\
\hline & Fat & 62.62 & & & Obese & 64.44 & & \\
\hline & Thin & 14.53 & & & Not obese & 13.44 & & \\
\hline \multirow[t]{3}{*}{ Depression } & Normal & 12.64 & 19.057 & $.000 * *$ & & & 55297.00 & .538 \\
\hline & Fat & 16.21 & & & Obese & 12.97 & & \\
\hline & Thin & 0.41 & & & Not obese & 0.41 & & \\
\hline \multirow[t]{2}{*}{ School event } & Normal & 0.43 & 1.532 & .465 & & & 48659.50 & $.002 * *$ \\
\hline & Fat & 0.45 & & & Obese & 0.62 & & \\
\hline
\end{tabular}

Note. $\mathrm{BMI}=$ Body Mass Index.

$* p<.05$. ** $p<.01$.

standard deviation of 3.02. After calculation of the physical inactivity index, the data were grouped into classes, as described above. It was observed that $44.0 \%$ of the sampled showed a high level of physical inactivity, while $41.9 \%$ showed low physical inactivity, and $14.1 \%$ were at regular levels.

Relating physical inactivity to body image in adolescents using the Kruskal-Wallis test, it was noted that individuals who consider themselves "fat" then present higher indices on the physical inactivity scale (8.65), these differences being statistically significant $(H=8.403, p=.015)$ (see Table 5). Analyzing this relationship in greater detail, it was noted that the percentage of individuals who consider themselves "fat" is lower among those who had reduced physical inactivity $(9.6 \%)$ than among adolescents whose levels of physical inactivity were higher $(14.0 \%)$ or regular $(17.2 \%)$, the differences being statistically significant $\left(\chi^{2}=\right.$ 13.574, $p=.009$ ) (see Table 6).

It was noted that the relationship between physical inactivity and the BMI classes did not present statistically significant differences $(U=53196.00, p=.214)$ among obese individuals (7.75) and non-obese individuals (8.18) (Table 5). The same occurred when the chi-square test between physical inactivity and obesity was analyzed (see Table 7), since, again, no statistically significant differences were found $\left(\chi^{2}=1.218, p\right.$ $=.544$ ) among the classes, despite the percentage of obese adolescents being higher in those who presented regular physical inactivity (10.1\%) and lower physical inactivity (9.4\%), as opposed to those who had higher physical inactivity $(7.8 \%)$. 
Table 6

Sample Distribution in Sedentariness

\begin{tabular}{|c|c|c|}
\hline Sedentariness & $N$ & $\%$ \\
\hline Scarce & 502 & 41.9 \\
\hline Regular & 169 & 14.1 \\
\hline \multirow[t]{2}{*}{ High } & 527 & 44.0 \\
\hline & Total & 100.0 \\
\hline
\end{tabular}

Table 7

Chi-Square Test of Amount of Physical Inactivity as a Function of Body Image and Obesity (BMI)

\begin{tabular}{|c|c|c|c|c|c|c|c|c|c|}
\hline \multirow{2}{*}{ Sedentariness } & \multicolumn{3}{|c|}{ Body image } & \multicolumn{6}{|c|}{ Obesity (BMI) } \\
\hline & Thin $(\%)$ & Normal (\%) & Fat $(\%)$ & $\chi^{2}$ & $p$ & Not Obese $(\%)$ & Obese $(\%)$ & $\chi^{2}$ & $p$ \\
\hline Scarce & 14.2 & 76.2 & 9.6 & \multirow{3}{*}{13.574} & \multirow{3}{*}{$.009 * *$} & 90.6 & 9.4 & \multirow{3}{*}{$\begin{array}{l}1.21 \\
8\end{array}$} & \multirow{3}{*}{.544} \\
\hline Regular & 13.0 & 69.8 & 17.2 & & & 89.9 & 10.1 & & \\
\hline High & 18.2 & 67.7 & 14.0 & & & 92.2 & 7.8 & & \\
\hline
\end{tabular}

Note. BMI = Body Mass Index.

$* * p<.01$.

Table 8

Sample Distribution as a Function of Socioeconomic Class

\begin{tabular}{|c|c|c|}
\hline Socioeconomic class & $N$ & $\%$ \\
\hline High & 65 & 5.4 \\
\hline Middle-high & 225 & 18.8 \\
\hline Middle & 698 & 58.3 \\
\hline Middle-low & 204 & 17.0 \\
\hline \multirow[t]{2}{*}{ Low } & 6 & 0.5 \\
\hline & Total & 100.0 \\
\hline
\end{tabular}

\section{Socioeconomic Level}

The data relative to socioeconomic level in the sample gave a minimum value of $<\mathrm{s} 1 /<7$ and a maximum value of 24 on the Graffer scale, with an average of 15.12 and a standard deviation of 2.81. According to Sousa (1999), the socioeconomic level data were groups into five classes. Thus, the middle class was most representative $(58.3 \%)$, followed by upper middle (18.8\%) and lower middle $(17.0 \%)$. The most distant classes were high and low classes, who were represented at lower levels $(5.4 \%$ and $0.5 \%$, respectively).

Analysis of the relationship between socioeconomic level and body image through the Kruskal-Wallis test indicated that, although there were no statistically significant differences $(H=0.034, p=.983)$ (see Table 9), the individuals who considered themselves "fat" tent to be from higher socioeconomic classes $(15.9 \%)$ than those who considered themselves "thin" $(15.07 \%)$. The absence of statistically significant differences was verified again in reference to socioeconomic classes $\left(\chi^{2}=9.817, p=.278\right)$ (see Table 9), although it was noted that the percentage of persons who considered themselves "fat" $(33.3 \%)$ in the lower classes was greater than in the others.

Relative to the relationship between socioeconomic classes and BMI classes, no statistically significant differences were found using the Mann-Whitney test ( $U=$ 54822.50, $p=.446$ ) (see Table 5), nor with the Chi-square test $\left(\chi^{2}=5.701, p=.223\right)$ (see Table 7$)$.

\section{Family Functionality}

Among the questioned individuals, the values for family functionality/APGAR test varied from 0 to 10 . The average was 6.59, and the standard deviation was 2.56. Grouping of the data in these three classes defended by Sousa, it was noted that the class method corresponds to "highly functional family", with $55.8 \%$, followed by the "moderately dysfunctional family" (30.4\%), and "highly dysfunctional family" (13.9\%). 
Table 9

Chi-Square Test of Socioeconomic Classes as a Function of Body Image and Obesity (BMI)

\begin{tabular}{|c|c|c|c|c|c|c|c|c|c|}
\hline \multirow{2}{*}{ Socioeconomic class } & \multicolumn{3}{|c|}{ Body image } & \multicolumn{6}{|c|}{ Obesity (BMI) } \\
\hline & Thin $(\%)$ & Normal (\%) & Fat $(\%)$ & $\chi^{2}$ & $p$ & Not Obese $(\%)$ & Obese $(\%)$ & $\chi^{2}$ & $p$ \\
\hline High class & 20.0 & 70.8 & 9.2 & & & 92.3 & 7.7 & & \\
\hline Middle-high class & 14.7 & 72.4 & 12.9 & & & 92.9 & 7.1 & & \\
\hline Middle class & 15.1 & 71.0 & 13.9 & 9.817 & .278 & 90.7 & 9.3 & 5.701 & .223 \\
\hline Middle-low class & 18.6 & 73.0 & 8.3 & & & 91.7 & 8.3 & & \\
\hline Low class & 0.0 & 66.7 & 33.3 & & & 66.7 & 33.3 & & \\
\hline
\end{tabular}

Note . BMI = Body Mass Index.

Table 10

Sample Distribution as a Function of Family Functionality

\begin{tabular}{|c|c|c|}
\hline Family attachment & $N$ & $\%$ \\
\hline Marked dysfunctionality & 166 & 13.9 \\
\hline Moderate dysfunctionality & 364 & 30.4 \\
\hline \multirow[t]{2}{*}{ Highly dysfunctional } & 668 & 55.8 \\
\hline & Total & 100.0 \\
\hline
\end{tabular}

After analysis of Table 11, no statistically significant differences were observed $(H=21.097, p=.000)$ between the body image classes in reference to the family functionality index. Or, rather, it was noted that adolescents who perceive themselves as "fat" are those who have lower APGAR family scores (5.89), followed by those who consider themselves "thin" (6.14), and then by those who consider themselves "normal" (6.82). Execution of chi-square text among the family functionality classes and the body image classes allowed verification of the existence of statistically significant differences among the classes $\left(\chi^{2}=25.806, p=.000\right)$ (see Table 11). Families with greater dysfunction are those where the adolescents tend to have a more negative body image, since the percentage of individuals that considered themselves "thin" $(23.0 \%)$ and "fat" (20\%) is greater than the remainder, with families with moderate dysfunction following $(15.1 \%$ and $14.6 \%$, respectively), and finally, the highly functional families ( $14.4 \%$ and $9.7 \%$, respectively).
Relative to the relationship between family functionality and obesity, analysis of Table 11 verifies that there are no statistically significant differences among the classes $(U=$ 53068.50, $p=.199$ ), although it was noted that obese adolescents (6.87) have an average index of family functionality greater than that of non-obese subjects (6.57). The same occurs with the chi-square test, as there were no statistically significant differences $\left({ }_{-}^{2}=2.512, p=.285\right)$, despite the fact that in the highly functional families the percentage of obese adolescents is greater (9.9\%).

\section{Self-Concept}

In the analysis of self-concept, the index obtained from the entire measurement scale was analyzed. Thus, the overall index from the Clinical Self-concept Inventory varied between 18 and 90, with an average index of 63.88 and a standard deviation of 7.40 .

Table 11

Chi-Square Test of Types of Family Functionality as a Function of Body Image and Obesity (BMI)

\begin{tabular}{|c|c|c|c|c|c|c|c|c|c|}
\hline \multirow{2}{*}{$\begin{array}{l}\text { Types of family } \\
\text { functionality }\end{array}$} & \multicolumn{3}{|c|}{ Body image } & \multicolumn{6}{|c|}{ Obesity (BMI) } \\
\hline & Thin $(\%)$ & Normal $(\%)$ & Fat $(\%)$ & $\chi^{2}$ & $p$ & Not Obese (\%) & Obese $(\%)$ & $\chi^{2}$ & $p$ \\
\hline Marked dysfunctionality & 23.0 & 57.0 & 20.0 & & & 93.4 & 6.6 & & \\
\hline Moderate dysfunctionality & 15.1 & 70.3 & 14.6 & 25.806 & $.000 * *$ & 92.3 & 7.7 & 2.512 & .285 \\
\hline Highly dysfunctional & 14.4 & 75.9 & 9.7 & & & 90.1 & 9.9 & & \\
\hline
\end{tabular}

Note. BMI = Body Mass Index.

$* * p<.01$. 
We also analyzed the relationship between self-concept and body image, for which we used the Kruskal-Wallis test, and found statistically significant differences between the body image classes $(H=7.237, p=.027)$ (see Table 5$)$. In fact, it was verified that the adolescents that considered themselves "fat" or "thin" had, on average, a lower selfconcept index than the remaining subjects $(62.62,63.50$, and 64.19).

No statistically significant differences were found in references to self-concept and obesity ( $U=55834.00, p=$ .647). However, it was noted that obese adolescents were those who had a higher self-concept index (64.44 vs. 63.83).

\section{Depression}

For the depression evaluation with the BDI, the minimum value obtained was 0 and the maximum 62 , with an average of 13.40 and a standard deviation of 9.98. Grouping the data in two classes (Gorestein \& Andrade, 1998), we found that the majority of adolescents questioned (52.5\%) appear to have depressive symptoms, while $47.5 \%$ had no, or only minimal indications of depression. Among the subjects with depression, the majority of the depressive pathologies were mild $(26.5 \%)$, followed by moderate depression $(17.5 \%)$ and, finally, severe depression $(8.5 \%)$.

With the Kruskal-Wallis statistically significant differences were found $(H=19.057, p=.000)$ among the body image classes, according to the depression index (see Table 12). Thus, the adolescents that considered themselves "fat" were those who had the greatest depression index
(16.21), followed by those who considered themselves "thin" (14.53), and then those who considered themselves "normal" (12.64). Also, analysis of the Chi-square text conducted between the depression and body image classes showed that differences between these classes are statistically significant $\left(\chi^{2}=18.259, p=.006\right)$ (see Table 13). In fact, we found that the greatest percentage of adolescents that considered themselves "fat" presented serious depression (19.6\%), followed by cases of moderate depression (15.95), mild $(13.2 \%)$, and minimal or nonexistent $(9.8 \%)$.

There were no statistically significant differences noted in the relationship between self-concept and obesity $(U=$ 55297.00, $p=.538$ ), but it was noted that obese adolescents had lower depression indexes (12.97 vs. 13.44) (cf. Table 5). Additionally, the chi-square text showed similar results, as there were no statistically significant differences between the classes $\left(\chi^{2}=0.632, p=.889\right)$ (see Table 13).

\section{Academic Success}

In the statistics regarding the number of failures the minimum value was 0 and the maximum 5 , with an average of 0.43 and a standard deviation of 0.74 . Yet, it was verified that $68.8 \%$ of adolescents reported no failures, while $21.7 \%$ reported having failed one time.

To analyze the relationship between academic success and body image, the Kruskal-Wallis test was used (see Table $5)$, verifying the absence of statistically significant differences between the classes $(H=1.532, p=.465)$. However, despite not being statistically significant, it was verified that

Table 12

Sample Distribution as a Function of Types of Depression

\begin{tabular}{|c|c|c|}
\hline Depression & $N$ & $\%$ \\
\hline Without depression & 569 & 47.5 \\
\hline Mild depression & 318 & 26.5 \\
\hline Moderate depression & 209 & 17.5 \\
\hline \multirow[t]{2}{*}{ Severe depression } & 102 & 8.5 \\
\hline & Total & 100.0 \\
\hline
\end{tabular}

Table 13

Chi-Square Test of Types of Depression as a Function of Body Image and Obesity (BMI)

\begin{tabular}{|c|c|c|c|c|c|c|c|c|c|}
\hline \multirow{2}{*}{ Types of depression } & \multicolumn{3}{|c|}{ Body image } & \multicolumn{6}{|c|}{ Obesity (BMI) } \\
\hline & Thin $(\%)$ & Normal $(\%)$ & Fat $(\%)$ & $\chi^{2}$ & $p$ & Not Obese (\%) & Obese $(\%)$ & $\chi^{2}$ & $p$ \\
\hline Without depression & 13.4 & 76.8 & 9.8 & \multirow{4}{*}{18.259} & \multirow{4}{*}{$.006 * *$} & 91.2 & 8.8 & \multirow{4}{*}{0.632} & \multirow{4}{*}{.889} \\
\hline Slight depression & 17.6 & 69.2 & 13.2 & & & 91.2 & 8.8 & & \\
\hline Moderate depression & 19.2 & 64.9 & 15.9 & & & 90.4 & 9.6 & & \\
\hline Severe depression & 16.7 & 63.7 & 19.6 & & & 93.1 & 6.9 & & \\
\hline
\end{tabular}

Note. BMI = Body Mass Index.

$* * p<.01$. 
adolescents who considered themselves "fat" were those who had the worst academic success ( 0.45 failures) and those who considered themselves "thin" had the greatest academic success (0.41 failures).

A similar situation occurred while analyzing the relation between depression and obesity, wherein the obese adolescents had the worst academic performance $(0.62$ failures) compared to non-obese adolescents ( 0.41 failures), these differences being statistically significant $(U=48659.50$, $p=.002)$ (see Table 5).

\section{Body Image and Obesity}

In the analysis of the relationship between the BMI and body image in adolescents using the Kruskal-Wallis test, it was verified that the individuals who considered themselves "fat" were those who, in fact, had the greatest BMI (24.24 $\mathrm{Kg} / \mathrm{m}^{2}$ ), followed by those who considered themselves "normal" $\left(21.63 \mathrm{Kg} / \mathrm{m}^{2}\right)$, and last, those who considered themselves "thin" $\left(19.83 \mathrm{Kg} / \mathrm{m}^{2}\right)$. These differences were statistically significant, as a level of significance of $p=.000$ was obtained (see Table 5).

Intending to analyze this relation in greater detail, we also considered the BMI grouped in pre-defined classes, verifying that both obese individuals, as much as non-obese, tend to consider themselves "normal" $(51.4 \%$ and $73.5 \%$, respectively). However, the percentage of obese adolescents who considered themselves "fat" $(46.7 \%)$ is greater than the percentage of non-obese adolescents who considered themselves "fat" $(9.3 \%)$, which is also a statistically significant difference $(p=.000)$ (see Table 14).

\section{Discussion}

The relationship between body image and obesity was evaluated in this study, with socio-demographic, psychological and behavioral data in adolescents. After analysis of the data, it was noted that the percentage of individuals that considered themselves "fat" is greater than the actual prevalence of obesity in the sample studied (12.7\% and $8.8 \%$, respectively). These results appear to confirm the tendency of individuals to overestimate their weight, considering themselves overweight, when, effectively, they are not (Veggi, Lopes, Faerstein, \& Sichieri, 2004).

As far as the relationship between academics, as much in relation to obesity as to body image, there where no statistically significant differences found between schools/locations. This may indicate that the schools are located in very similar socioeconomic and cultural environments, not confirming the relationship between location defended by various authors (Cardoso \& Vieira, 1990; Lissau \& Sorensen, 1994, in Mahan \& Escott-Stump, 1996/1998). At the Secondary school at Moimenta da Beira, the prevalence of obese adolescents is equal to the prevalence of adolescents who consider themselves "fat", seeming to have a body image adjusted to the reality.

In relation to gender, statistically significant differences were noted both for body image (Connors \& Casey, 2006; Varnado-Sullivan, Horton, \& Savoy, 2006; Wang, Byrne, Kenardy, \& Hills, 2005), and for obesity (Monteiro, et al., 2000; Santiago, Mesquita, Carvalho, \& Rocha, 1998; Sichieri \& Veiga, 2002). Overall, whereas obesity is largely associated with males, females are more likely to consider themselves "fat". Or, rather, females seem to overestimate their weight more frequently, having a body image that does not reflect reality.

In reference to age, we verified that there were no statistically significant differences between body image classes, but that there were between obese and non-obese adolescents (obese adolescents tending to be older). Or, age does not appear to be related to body image (not proving, thus, the data from Wang, Byrne, Kendardy, and Hilles (2005)), contrary to what occurs with obesity (Kanbur, Derman, \& Kinik, 2002; Laitinen, Power, \& Jarvelin, 2001).

In the analysis of the relationship with physical inactivity, it was noted that individuals who considered themselves "fat" had higher levels of physical inactivity compared to individuals who considered themselves "thin", and the differences were statistically significant. Analyzing this relationship in greater detail, we verified that adolescents who considered themselves "fat" tend to have a regular or elevated level of physical inactivity. This is contrary to the study from Varnado-Sullivan et al. (2006). There were no statistically significant differences found in reference to the BMI, contrary to the hypotheses defended by Bray

Table 14

Chi-Square Test of Types of Obesity (BMI) and Body Image

\begin{tabular}{|c|c|c|c|c|c|c|c|c|}
\hline \multirow{3}{*}{ Types of obesity (BMI) } & \multicolumn{6}{|c|}{ Body image } & \multirow{3}{*}{$\chi^{2}$} & \multirow{3}{*}{$p$} \\
\hline & \multicolumn{2}{|c|}{ Thin } & \multicolumn{2}{|c|}{ Normal } & \multicolumn{2}{|c|}{ Fat } & & \\
\hline & $N$ & $\%$ & $N$ & $\%$ & $N$ & $\%$ & & \\
\hline Not obese & 187 & 17.1 & 803 & 73.5 & 102 & 9.3 & 126.384 & $.000 * *$ \\
\hline Obese & 2 & 1.9 & 54 & 51.4 & 49 & 46.7 & & \\
\hline
\end{tabular}

$* * p<.01$. 
(1996/1997), Guerreiro (2001), and Padez (2002). Rather, physical activity/physical inactivity appear to be related, overall, with body image to the detriment of obesity. One of the limitations of the study resides in the fact that it is not possible to divulge the psychometric data from the physical inactivity scale, as chosen by the authors of the study. It was not possible to work around this situation, since this was the only scale available to evaluate this construct in this population.

Upon analysis, we determined that the socioeconomic level had no significant relation with either body image or obesity. These results did not confirm the data provided by Wang et al. (2005), nor those of Laitinen, Power and Jarvelin (2001), respectively, but did corroborate the conclusion of Rodriguez, Novalbos, Martinez, Escobar and Castro (2004), that socioeconomic level is not related to body image.

Family functionality appears to bear a significant relation to body image, but not with obesity. In fact, we noted the existence of statistically significant differences between the body image classes in relation to family functionality (the adolescents who considered themselves "fat" tend to have less functional families, and those with families with elevated levels of dysfunction tend to have more adolescents considered "fat" than the remainder), which corroborates the data from Rodriguez et al. (2004). The relationship between BMI/obesity and family functionality was not statistically significant, which diverges from the conclusions from Fontoura, Duarte, Simas, Rebelo, and Guerreiro (1991).

A significant relationship was established between selfconcept and body image, but not with obesity. In fact, it was verified that adolescents that consider themselves "fat" have a lower self-concept index than the other individuals (statistically significant differences), which corroborates the findings of Carvalho, Pedrão, and Loureiro (2006). However, as we found not statistically differences between BMI and self-concept, we could not confirm the results of Datar, Sturm, and Magnabosco (2004) and of Falkner, NeumarkSztainer, Story, Jeffery, Beuhring, and Resnick (2001).

A similar situation was found when depression was considered, since it also appeared to relate significantly only with body image, and not with obesity, identical to the results from Daniels (2005). In fact, it was verified that adolescents who considered themselves "fat" have higher depression indexes and tend to develop sever depression. The BMI/obesity did not show statistically significant differences in reference to depression, and, as such, we could not confirm the statements from Datar et al. (2004) nor those from Zeller, Saelens, Roehrig, Kirk, and Daniels (2004).

In reference to academic success, we observed that this only could be made sense of in a statistically significant manner for the BMI/obesity, and not for body image. Thus, results from Bandeira and Hutz (1994) and from Macedo, Andreucci, and Montelli (2004a, 2004b), which state that body image is significantly related to academic success, could not be confirmed. On the other hand, we noted that obese adolescents have a lower academic success rate than non-obese adolescents, as has been noted by various other authors (Datar et al., 2004; Falkner et al., 2001).

Finally, we would like to note that, despite body image being related in a statistically significant manner with BMI/obesity (Conti, 2002) and while the majority of people tend to overestimate their weight, only $46.7 \%$ of the obese adolescents confirmed that they consider themselves to be "fat".

\section{Conclusions}

In conclusion, obesity appear to be one of the most important scourges of contemporary society, affecting our adolescents in particularly, since they are in a phase marked by important development and profound transformation at the physiological, cognitive, affective, social and moral level, as well as in the realm of construction of their identity and autonomy. Thus, it seems important to us to determine the mean in which adolescents construct their body image, whether obese or not, comparing individual and sociofamiliar variables.

In this way, our study verified that the prevalence of obesity in the sample was $8.8 \%$, while $12.7 \%$ of adolescents believed themselves to be "fat". These last showed a higher rate of physical inactivity, and lower family functionality, and lower self-concept index, and a higher depression index. Adolescents who truly are obese were older and had lower academic success rates. We also found that obesity is more prevalent in males, but females tend to be more likely to consider themselves "fat".

These results underline the importance of evaluate weight perception/body image with the BMI, since, at times, the problems is not only in being obese, but also in the selfrepresentation of a weight greater than the ideal.

\section{References}

Bandeira, D., \& Hutz, C. (1994). A contribuição dos testes DFH, Bender e Raven na predição do rendimento escolar na primeira série. Psicologia, Teoria e Pesquisa, 10, 59-72.

Beck, A.T., Rush, A.J., Shaw, B.F., \& Emery, G. (1979). Cognitive therapy of depression. New York: Guilford Press. (Portuguese translation: C. Gorestein \& L. Andrade, (1998). Inventário de depressão de Beck: propriedades psicométricas da versão em português. Revista de Psiquiatria Clínica, 25, 245-250).

Bosi, M. L. M., Luiz, R. R, Morgado, C. M., Costa, M. L., \& Carvalho, R. J. (2006). Autopercepção da imagem corporal entre estudantes de nutrição: um estudo no município do Rio de Janeiro. Jornal Brasileiro de Psiquiatria, 55, 108-113.

Bray, G. (1996). Obesity. In E.E. Ziegler \& L.J. Filer (Eds.), Present knowledge in nutrition (pp. 19-32) ( $7^{\text {th }}$ ed.). Washington DC: International Life Sciences Institute Press. 
Cardoso, S., \& Vieira, D. (1990). Excesso de peso e obesidade nos mancebos portugueses: análise a nível nacional e regional. Revista Portuguesa de Nutrição, 2, 21-38.

Carvalho, A., Pedrao, L., \& Loureiro, S. (2006). Autoconceito e imagem corporal de crianças obesas e não obesas. Unpublished Master's dissertation, Escola de Enfermagem de Ribeirão Preto (Brazil).

Connors, J., \& Casey, P. (2006). Sex, body-esteem and self-esteem. Psychological Reports, 98, 699-704.

Conti, M. (2002). Imagem corporal e estado nutricional de estudantes de uma escola particular. Unpublished Master's dissertation, Universidade de São Paulo (Brazil).

Cruz, J. (1983). Prevenção versus tratamento da obesidade. Servir, 6, 309-323.

Daniels, J. (2005). Weight and weight concerns: Are they associated with reported depressive symptoms in adolescents? Journal of Pediatric Health Care, 19, 33-41.

Datar, A., Sturm, R., \& Magnabosco, J. (2004). Childhood overweight and academic performance: National study of kindergartners and first-graders. Obesity Research, 12, 58-68.

Falkner, N. H., Neumark-Sztainer, D., Story, M., Jeffery, R. W., Beuhring, T., \& Resnick, M. D. (2001). Social, educational, and psychological correlates of weight status in adolescents. Obesity Research, 9, 32-42.

Fonseca, M., Faerstein, E., Chor, D., \& Lopes, C. (2004). Validade de peso e estatura informados e índice de massa corporal: estudo pró-saúde. Revista de Saúde Pública, 38, 392-398.

Fontoura, M. E., Duarte, J. S., Simas, M. J., Rebelo, M., \& Guerreiro, L. (1991). Obesidade infantil - aspectos particulares. Revista Portuguesa de Nutrição, 3, 19-27.

Gomes, C., Ferreira, H., Rocha, M., Almeida, M., \& Sousa, P. (2004). Obesidade na Adolescência. Revista Sinais Vitais, 56, 23-26.

Gorestein, C., \& Andrade, L. (1998). Inventário de depressão de Beck: propriedades psicométricas da versão em português. Revista de Psiquiatria Clínica, 25, 245-250.

Guerreiro, S. (2001). Emagrecer com conta, peso e medida. Medicina \& Saúde, 43, 38-39.

Kanbur, N., Derman, O., \& Kinik, E. (2002). Prevalence of obesity in adolescents and the impact of sexual maturation stage on body mass index in obese adolescents. International Journal of Adolescent Medicine and Health, 14, 61-65.

Laitinen, J., Power, C., \& Jarvelin, M. (2001). Family social class, maternal body mass index, childhood body mass index, and age at menarche as predictors of adult obesity. American Journal of Clinical Nutrition, 3, 287-294.

Macedo, C., Andreucci, L, \& Montelli, T. (2004a). Cognitive function evaluation in school-age children from economically impoverished community: Results of enriched education program. Arquivos de Neuro-Psiquiatria, 62, 204-209.

Macedo, C., Andreucci, L., \& Montelli, T. (2004b). Alterações cognitivas em escolares de classe socio-económica desfavorecida. Arquivos de Neuropsiquiatria, 62, 852-857.

Mahan, L. K., \& Escott-Stump, S. (1996). Krause's food nutrition and diet therapy ( $9^{\text {th }}$ ed.). Philadelphia, PA: W.B. Saunders Company. (Portuguese translation: Alimentos, Nutrição $e$ Dietoterapia (9 $9^{\text {th }}$ ed.). São Paulo: Editora Afiliada, 1998).
Martins, P. O., Trindade, Z. A., \& Almeida, A. M. O. (2003). O Ter e o Ser: representações sociais da adolescência entre adolescentes de inserção urbana e rural. Psicologia: Reflexão e Crítica, 16, 555-568.

Medeiros, M. T. (2000). Conceito de adolescência. In M. T. Medeiros \& A. I. Serpa (Org.), Adolescência: abordagens, investigações e contextos de desenvolvimento (pp. 12-27). Açores: Direcção Regional da Educação.

Monteiro, P., Victora, C., Barros, F., \& Tomasi, E. (2000). Diagnóstico de sobrepeso em adolescentes: estudo do desempenho de diferentes critérios para o Índice de Massa Corporal. Revista de Saúde Pública, 34, 506-513.

Nunes, M., Olinto, M., Barros, F., \& Camey, S. (2001). Influência da percepção do peso e do índice de massa corporal nos comportamentos alimentares anormais. Revista Brasileira de Psiquiatria, 23, 21-27.

Padez, C. (2002). Actividade física, obesidade e saúde: uma perspectiva evolutiva. Revista Portuguesa de Saúde, 1, 1120.

Pestana, M. \& Gageiro, J. (1998). Análise de Dados para Ciências Sociais - A Complementaridade do SPSS. Edições Sílabo: Lisboa.

Rodriguez, M., Novalbos, R., Martinez, N., Escobar, J., \& Castro, D. (2004). Epidemiological study of the influence of family and socioeconomic status in disorders of eating behaviour. European Journal of Clinical Nutrition, 58, 846-52.

Saikali, C. J., Soubhia, C. S., Scalfaro, B. M., Cordás, T. A. (2004). Imagem corporal nos transtornos Alimentares. Revista de Psiquiatria Clínica, 31, 164-166.

Santiago, L., Mesquita, E., Carvalho, I., \& Rocha, M. (1998). Excesso ponderal e obesidade em jovens - estudo observacional de base populacional. Saúde Infantil, 20 , p. 13-20.

Santos, V., \& Sawaia, B. (2000). A bolsa na mediação "estar ostomizado"-"estar profissional": análise de uma estratégia pedagógica. Revista latino-americana de enfermagem, 8, 4050.

Segal, A., Cardeal, M. V., \& Cordás, T. A. (2002). Aspectos psicossociais e psiquiátricos da obesidade. Revista de Psiquiatria Clínica, 29, 81-89.

Sichieri, R., \& Veiga, G. V. (2002). Obesidade na adolescência. Retrieved on January 4, 2005, at: www.bireme.br/bvs/adolec/ $\mathrm{P} /$ cadernos/capitulo/cap26/cap26.htm.

Smilkstein, G., Ashworth, C., \& Montano, D. (1982). Validity and reliability of the Family APGAR as a test of family function. Journal of Family Practice, 15, 56-60.

Sousa, D. (1999). A pessoa com acidente vascular cerebral e a família no distrito de Viseu: a recuperação do doente com AVC e implicações psicossociais. Unpublished Master's dissertation, Universidade de Coimbra (Portugal).

Traverso-Yepez, M. A., \& Pinheiro, V. S. (2002). Adolescência, saúde e contexto social: esclarecendo práticas. Psicologia \& Sociedade, 14, 133-147.

Universidade Estatal de Campinas (1997). Obesidade na infância e Adolescência. Retrieved on December 4, 2002, at: www.hospvirt.org.br/enfermagem/port/obesidad.htm. 
Varnado-Sullivan, P., Horton, R., \& Savoy, S. (2006). Differences for gender, weight and exercise in body image disturbance and eating disorder symptoms. Eating and Weight Disorders, 11, 118-25.

Vaz Serra, A. (1986). O "Inventário Clínico do Auto-Conceito". Psiquiatria Clínica, 7, 67-84.

Veggi, A., Lopes, C., Faerstein, E., \& Sichieri, R. (2004). Índice de massa corporal, percepção do peso corporal e transtornos mentais comuns entre funcionários de uma universidade no Rio de Janeiro. Revista Brasileira de Psiquiatria, 26, 242247.
Wang, Z., Byrne, N., Kenardy, J., \& Hills, A. (2005). Influences of ethnicity and socioeconomic status on the body dissatisfaction and eating behaviour of Australian children and adolescents. Eating and Behaviour, 6, 23-33.

Zeller, M., Saelens, B., Roehrig, H., Kirk, S., \& Daniels, S. (2004). Psychological adjustment of obese youth presenting for weight management treatment. Obesity Research, 12, 1576-1586.

Received November 15, 2006 Revision received November 17, 2007 Accepted November 22, 2007 